\title{
EVALUATION OF ATTITUDES OF HIGH SCHOOL STUDENTS (15-17 AGE GROUP) IN PHYSICAL EDUCATION LESSONS
}

\author{
Ozturk M.E ${ }^{1} \mathbb{}$, Yazici A.G ${ }^{1}$, Ogan M ${ }^{1}$ iD, Ozdemir $K^{1}$ \\ ${ }^{1}$ Atatürk Üniversity, Physical Education and Sports Department, Erzurum, Turkey
}

DOI: https://doi.org/10.29121/granthaalayah.v8.i9.2020.693

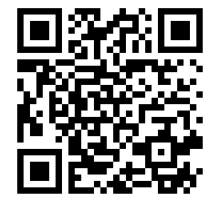

Article Type: Research Article

Article Citation: Ozturk M.E, Yazici A.G, Ogan M, and Ozdemir K. (2020). EVALUATION OF ATTITUDES OF HIGH SCHOOL STUDENTS (15-17 AGE GROUP) IN PHYSICAL EDUCATION LESSONS. International Journal of Research GRANTHAALAYAH, 8(9), 383-387. https://doi.org/10.29121/granthaa layah.v8.i9.2020.693

Received Date: 15 July 2020

Accepted Date: 30 September 2020

Keywords:

Physical Education

Highschool Students

Attitude

\section{ABSTRACT}

This study was conducted to evaluate the behavior of highschool students who take Physical Education Lesson classes within the Erzurum city center. The population of the study consists of high school students affiliated with the Ministry of National Education, and the sample consists of high school students in Erzurum city center. In the study, random sampling method was used and 100 students participated. In order to determine the socio-demographic characteristics of the subjects, frequency and percentage analysis, independent t-test to determine differences between genders, one-way analysis of variance (ANOVA) test to determine differences between other characteristics was used.

As a result, if these differences are thought to be in adolescence, it can be said that their attitudes towards physical education lesson in this period are taking shape. In this respect, it is seen that secondary school students have a important period in the sense of attitude formation. Therefore, the direction and strength of the attitudes of secondary school students should be measured. The attitude of highschool students towards physical education and sport lessons according to their age, number of siblings, family members' sports status and family income levels were examined.

\section{INTRODUCTION}

Physical education is all of regular, theoretic studies that are carried out in order to provide the physical and physical development of the person, to prepare for the conditions of daily life and work life, and to strengthen the national consciousness and citizenship feelings (Erhan ve Tamer, 2009). All knowledge, skills, attitudes and habits intended to be gained in physical education courses should be evaluated (Başoğlu, 1995).

In Literature, Attitude was first used by Harbert Spencer in 1862 to express the individual's mental state. The term was examined and studied by Lange in 1888 in laboratory studies. (Yazicl ve ark, 2016). Although there are significant differences between the definitions used today about the concept of attitude, Lange made a close description to these definitions. later on, the concept of attitude has become a popular topic which researched and discussed by psychologists and sociologists. Moreover, it has been claimed that these researches and discussions lead to the birth of social psychology. (Güllü 2009).

Attitude is a continuous organization of motivation, excitement, cognition, and learning processes with the aspect of individual's own perception world. While attitude come near or away from some objects, concepts and situations; it also refers to the readiness to act against them. According to the Franzoi (2003, Attitude is an individual's evalution of an object as positive or negative. (Güllü 2009) Positive attitudes of students towards the

(C) 2020 The Author(s). This is an open access article distributed under the terms of the Creative Commons Attribution License, which permits unrestricted use, distribution, and reproduction in any medium, provided the original author and source are credited. 
physical education lesson can provide efficient processing of lesson activities and facilitate the achievement of specific and general objectives of the lesson or enable students to participate voluntarily in various physical activities in the future. (Silverman ve Scrabis, 2004)

On the contrary of this case, the students who has negative attitudes related to the physical education lesson can decrease the effectiveness of lesson, may not attent to lesson, disregard the lesson or may cause various problems.

\section{FINDINGS}

Conducted tests: Frequency / descriptive statistics / Reliability analysis / Normality analysis / Independent Student T test, Anova

Reliability analysis result: Cronbach's Alpha .874

Table 1: Demographic Features of Students

\begin{tabular}{|c|c|c|c|}
\hline Variable & & $\mathrm{f}$ & $\%$ \\
\hline \multirow{3}{*}{ Number of siblings } & 2 & 25 & 24.5 \\
\cline { 2 - 4 } & 3 & 40 & 39.8 \\
\cline { 2 - 4 } & 4 & 21 & 21.4 \\
\cline { 2 - 4 } & 5 and over & 14 & 14.3 \\
\hline \multirow{3}{*}{ Age } & 15 years & 33 & 32.7 \\
\cline { 2 - 4 } & 16 years & 44 & 43.9 \\
\cline { 2 - 4 } & 17 years & 23 & 23.5 \\
\hline Anyone doing sports in the family? & Yes & 55 & 55.1 \\
\cline { 2 - 4 } & No & 45 & 44.9 \\
\hline Family income & $0-2000$ tl & 30 & 30.6 \\
\cline { 2 - 4 } & $2001-4000$ tl & 46 & 45.9 \\
\cline { 2 - 4 } & 4001 tl and over & 24 & 23.5 \\
\hline \multicolumn{2}{|c|}{ Total } & 100 & 100 \\
\hline
\end{tabular}

When the data in Table 1 is examined it is seen that, $24.5 \%$ of those with 2 siblings, $39.8 \%$ with 3 siblings, $21.4 \%$ with 4 siblings, and $14.3 \%$ with 6 or more. After examining the age data we can see that those who are 15 years old is $32.7 \%, 43.9 \%$ at the age of 16 and $23.5 \%$ at the age of 17 , While $55.1 \%$ answered yes to the question are there any sports in the family?, $44.9 \%$ answered no to the question. When the income group is examined, it can be seen that $0-2000 \mathrm{tl}$ is $30.6 \%, 2001-4000 \mathrm{tl}$ is $45.9 \%, 4001 \mathrm{tl}$ and above is $23.5 \%$.

Table 2: Average values of students Attitude tests

\begin{tabular}{|c|c|c|c|c|}
\hline & Minimum & Maximum & Mean & Std. Deviation \\
\hline I am waiting impatiently & 1 & 5 & 3.9082 & 1.34767 \\
\hline I Feel Fit & 1 & 5 & 3.8571 & 1.39217 \\
\hline I see the lesson unnecessary & 1 & 5 & 3.7143 & 1.52640 \\
\hline Good Stance & 1 & 5 & 3.7755 & 1.23130 \\
\hline Sport branches & 1 & 5 & 3.6939 & 1.35013 \\
\hline Basic skill & 1 & 5 & 3.9286 & 1.32579 \\
\hline How useful it is & 1 & 5 & 4.1531 & 1.11551 \\
\hline Out of school of activity & 1 & 5 & 3.7449 & 1.24612 \\
\hline My Information is Increasing & 1 & 5 & 3.6939 & 1.21340 \\
\hline Our Sincerity Is Strengthening & 1 & 5 & 3.6837 & 1.32849 \\
\hline Not trusted & 1 & 5 & 4.0510 & 1.13403 \\
\hline Playing friendly & 1 & 5 & 3.7449 & 1.29481 \\
\hline My comming & 1 & 5 & 3.9694 & 1.27185 \\
\hline Makes it Easy to Follow the Rules & 1 & 5 & 3.6939 & 1.21340 \\
\hline
\end{tabular}


Ozturk M.E, Yazici A.G, Ogan M, and Ozdemir K

\begin{tabular}{|c|c|c|c|c|}
\hline I am taking pleasure & 1 & 5 & 3.8980 & 1.29623 \\
\hline classroom interaction & 1 & 5 & 3.6531 & 1.40765 \\
\hline I think I have learned & 1 & 5 & 3.0612 & 1.75755 \\
\hline number of lesson hours should be more & 1 & 5 & 3.8061 & 1.46194 \\
\hline we are getting dressed but taking off the dress without doing anything & 1 & 5 & 3.3878 & 1.60304 \\
\hline I think it will be useless & 1 & 5 & 3.2041 & 1.58576 \\
\hline Physical Development & 1 & 5 & 3.8878 & 1.23424 \\
\hline I am relaxing and easing. & 1 & 5 & 3.9490 & 1.18733 \\
\hline I Know the Sport branches Better & 1 & 5 & 4.0918 & 1.14951 \\
\hline It is lazy students lesson & 1 & 5 & 3.2653 & 1.62170 \\
\hline Lesson Activities & 1 & 5 & 3.3163 & 1.64722 \\
\hline I am realizing my abilities & 1 & 5 & 3.1633 & 1.66029 \\
\hline I am keeping my health better & 1 & 5 & 3.9082 & 1.18484 \\
\hline Attending the lesson annoys me & 1 & 5 & 3.8776 & 1.27032 \\
\hline we are learning knowledge and skill & 1 & 5 & 3.1020 & 1.50935 \\
\hline It encourages to do sport. & 1 & 5 & 3.1633 & 1.63527 \\
\hline Coordination Developer Movement & 1 & 5 & 3.8878 & 1.36889 \\
\hline I am avoiding Harmful Habits & 1 & 5 & 3.9490 & 1.36505 \\
\hline I am attending to get a mark & 1 & 5 & 3.8061 & 1.42625 \\
\hline Encouraging to Breaking Rules & 1 & 5 & 3.4388 & 1.73542 \\
\hline Attitude. point & 1 & 5 & 4.0102 & 1.54982 \\
\hline
\end{tabular}

When the data in Table 2 was examined, it was found that the average value of the students' attitude test was found to be lowest with the expression "Attending the lesson annoys me" 3.1020 and "How Useful it is" was the highest average and 4.1531, and a statistically significant difference was found in the comparison of the data. It's standard deviation is 1,641 . On the attitude scale, 4.1531 has the highest average expression of "how useful sports are". The scale "I think I learned" with 3.0612 on the scale has the lowest average.

Table 3: Comparison of attitude points according to the students number of siblings

\begin{tabular}{|c|c|c|c|c|c|}
\hline Number of Siblings & $\mathrm{n}$ & Mean & Std. Deviation & $\mathrm{F}$ & $\mathrm{p}$ \\
\hline 2 & 24 & 126.7083 & 14.64798 & .259 & .855 \\
\cline { 1 - 5 } 3 & 39 & 130.7179 & 25.97666 & & \\
\cline { 1 - 4 } 5 & 21 & 128.4286 & 22.68385 & & \\
\hline 5 and over & 14 & 132.0714 & 14.91238 & & \\
\hline
\end{tabular}

When the data of Comparison of students attitude points according to the number of siblings is examined, it is seen that there are 24 persons that have 2 siblings, 39 persons have 3 siblings, 21 persons have 4 siblings and 14 persons have $5+$ siblings. Also no statistically significant difference was found in the comparison of the attitude scores of the students according to the number of siblings.

Table 4: Comparison of attitude points according to the ages of students

\begin{tabular}{|c|c|c|c|c|c|}
\hline Age & $\mathrm{n}$ & Mean & Std. Deviation & $\mathrm{F}$ & $\mathrm{p}$ \\
\hline 15 years & 32 & 128.1250 & 22.84555 & .407 & .667 \\
16 years & 43 & 128.5349 & 19.34443 & & \\
\hline 17 years & 23 & 132.9565 & 23.20752 & & \\
\hline
\end{tabular}

When the data of Comparison of students attitude points according to the number of siblings is examined, it was found that the highest average was 17 years. A statistically significant difference was found in the comparison of the attitudes of high school students according to their ages. A statistically significant difference was not found in the comparison of the attitudes of high school students according to their ages. 
Evaluation of Attitudes of High School Students (15-17 Age Group) in Physical Education Lessons

Table 5: Comparison of attitude points according to the family members doing sports

\begin{tabular}{|c|c|c|c|c|c|}
\hline Doing Sports & $\mathrm{N}$ & Mean & Std. Deviation & $\mathrm{t}$ & $\mathrm{p}$ \\
\hline Yes & 54 & 129.6667 & 19.37125 & .117 & .907 \\
\hline No & 44 & 129.1591 & 23.73589 & & \\
\hline
\end{tabular}

In Table 5, it can be seen that there was no significant difference between the attitudes of the family members towards physical education lesson according to their sporting status.

Table 6: Comparison of attitude points according to the students family income levels

\begin{tabular}{|c|c|c|c|c|c|}
\hline Income Status & $\mathrm{n}$ & Mean & Std. Deviation & $\mathrm{F}$ & $\mathrm{p}$ \\
\hline $0-2000 \mathrm{tl}$ & 30 & 127.9333 & 17.90961 & .395 & .675 \\
\cline { 1 - 5 } $2001-4000 \mathrm{tl}$ & 45 & 128.6889 & 23.99604 & & \\
\hline 4001tl and over & 23 & 132.8696 & 20.35884 & & \\
\hline
\end{tabular}

When the data in Table 6 is examined, the attitude scores of students with respect to their family income levels are highest average is $4001 \mathrm{tl}+$ with 132,869 . and the lowest average is $0-2000 \mathrm{tl}$ with 127.933 . There is not a significant difference in attitudes according to income status.

\section{DISCUSSION AND CONCLUSION}

In our attitude study; No significant difference was observed in the items presented according to age, number of siblings, family income and family sports. It has been observed that sport and physical education are influenced by features such as leisure activity, entertainment, protection from harmful habits, awareness of talents.

Another variable affecting the success in education is the attitude towards the elements such as student's topic, school, teacher etc. Students' positive attitudes towards education will increase his / her success. Research shows that collaborative learning positively affects students' attitudes towards school and learning. (Açlkgöz,1992).

Despite the lack of basic materials necessary for the processability of physical education course, students' attitudes towards physical education course are generally positive.

Güllü and Korucu (2005) in the results of the research that examined the views of secondary school students about physical education lessons stated that the attitudes of the students towards physical education courses were generally positive. Taşmektepligil, Yılmaz, İmamoğlu and Kılcıgil (2006) also found that students generally liked physical education. This information is in line with our study.

Erkmen et al. (2006) in their study to determine the attitudes of the students that attending private primary schools about physical education lesson according to various variables, stated that physical education and sports lessons that applied in the private primary schools are important in terms of students, and the students attitude and views towards this lesson are positive These findings are consistent with our study.

Richard and Tokie (2006) researched Japanese and British students' attitudes towards physical education in their study. As a result of this work, it is determined that students from both countries showed positive attitude towards physical education course. This information is in parallel with our study.

As a result, it is important to increase the quality of teaching service in the learning-teaching process in our age, where individual differences are essential, and to make the lessons enjoyable in order to provide a permanent learning. It can be said that in achieving the general objectives of education, cooperative teaching method will help this process because of the nature of the method. On the other hand, the contribution of each student individually to the group will increase the level of learning. Therefore, it can be said that using the cooperative teaching method in physical education classes can contribute to the learning of every student in the classroom.

\section{SOURCES OF FUNDING}

This research received no specific grant from any funding agency in the public, commercial, or not-for-profit sectors. 


\section{CONFLICT OF INTEREST}

The author have declared that no competing interests exist.

\section{ACKNOWLEDGMENT}

None.

\section{REFERENCES}

[1] Açılkgöz K.Ü. (1992) İşbirlikli Öğrenme, Kuram, araştırma, Uygulama. Malatya.

[2] Başoğlu, B. (1995) Ankara ili Devlet Liselerinde Görev Yapan Beden Eğitimi ve Spor Öğretmenlerinin Mesleki Sorunları Üzerine Bir Araştırma, Gazi Üniversitesi Sağlık Bilimleri Enstitüsü Yayımlanmış Yüksek Lisans Tezi, Ankara.

[3] Erhan S.E, Tamer K. (2009) Doğu Anadolu bölgesi ilköğretim ve ortaöğretim okullarında beden eğitimi dersi için gereken tesis araç-gereç durumları ile öğrencilerin beden eğitimi dersine ilişkin tutumları arasındaki ilişkiler. Atatürk Üniversitesi Beden Eğitimi ve Spor Bilimleri Dergisi,11(3),57-66.

[4] Erkmen, G, Tekin, M., Taşğın, Ö. (2006) Özel ilköğretim okullarında öğrenim gören öğrencilerin çeşitli değişkenlere göre beden eğitim dersi hakkındaki tutum ve görüşleri. 9. Uluslar Arası Spor Bilimleri Kongresi, 3-5 Kasım, Nobel Yayın Dağıtım Muğla Üniversitesi. Muğla.

[5] Güllü M, Güçlü M. (2009) Ortaöğretim öğrencileri için beden eğitimi dersi tutum ölçeği geliştirmesi, Niğde Üniversitesi Beden Eğitimi ve Spor Bilimleri Dergisi Cilt 3, sayı 2.

[6] Harriet D, Richard B. and Tokie I. (2006) Japanese and English school students' views of physical education: a comparative study. International Journal of Sport and Health Science, Vol. 4 pp.74- 85.

[7] Silverman, S. and Scrabis, K.A. (2004) A review of research on instructional theory in physical education 2002 2003. International Journal of Physical Education, 41, (1), 4-12.

[8] Taşmektepligil Y, Yılmaz Ç, İmamoğlu O ve Kılcıgil E. (2006) İlköğretim okullarında beden eğitimi ders hedeflerinin gerçekleşme düzeyi. Spormetre Beden Eğitimi ve Spor Bilimleri Dergisi,4 (4), 139-147.

[9] Yazıcı A. N, Kalkavan A, Özdilek Ç. (2016). Üniversite Öğrencilerinin Beden Eğitimi ve Spor Öğretimi Dersine İlişkin Tutumlarının Bazı Değişkenler Açısından İncelenmesi. International Journal of Science Culture and Sport (IntJSCS), 4:(SI 2): 404-411. 